\title{
Toothbrush: Knowledge and Practice of Undergraduate Students of Dental Therapy in Enugu, Nigeria
}

\section{Nathan Ukuoghene Ikimi ${ }^{1 *}$, Lawrence Igbinosa ${ }^{2}$ and Nkereuwem Sunday Etukudoh ${ }^{3}$}

${ }^{1}$ Consultant Family Dentistry, Dental and Maxillofacial Surgery Department, State

House Clinic, State House, Abuja-FCT, Nigeria

${ }^{2}$ Consultant Family Dentistry, Department of Oral Diagnosis and Dental Radiology,

UNIBEN/UBTH, Edo State, Nigeria

${ }^{3}$ Department of Haematology, Federal School of Medical Laboratory Sciences, Jos,

Plateau State, Nigeria

*Corresponding Author: Nathan Ukuoghene Ikimi, Consultant Family Dentistry, Dental and Maxillofacial Surgery Department, State House Clinic, State House,

Abuja-FCT, Nigeria.
Received: August 21, 2021

Published: September 18, 2021

(C) All rights are reserved by Nathan

Ukuoghene Ikimi., et al.

\begin{abstract}
Background: The Dental therapist in Nigeria is trained among other things, to carry out prophylactic cleaning of the teeth of patients and to give oral hygiene instructions. This in important for good oral hygiene status of the patient.

Objectives: This study was designed to find out if the dental therapist has enough knowledge to carry out her functions in the oral health care management of patients and if she is putting to practice what she is learning.

Method: This a descriptive cross-sectional questionnaire-based survey among 370 Dental therapy students at the Federal College of Dental Technology, Trans-Ekulu, Enugu State, Nigeria. The questionnaire was divided into three sections consisting of Biodata, Likert-scaled questions, and closed-ended questions to determine knowledge and practice. Data collected were analysed using SPSS statistical package, version 20.

Results: Most of the respondents, representing 74\% (206) have a good knowledge of toothbrushing when compared with the 26\% (74) whose knowledge is fair and $98.6 \%$ recommends changing of the toothbrush every 3 months. However, only $1.4 \%$ knew about decontamination of toothbrush using chlorhexidine gluconate or sodium hypochlorite. On the care of toothbrush, $96.4 \%$ reported that it is not recommended to keep toothbrush in the bathroom, while $100 \%$ completely disagreed with keeping toothbrush in a bathroom with attached toilet. The toothbrushing practice of respondents is good as shown by the $78.60 \%$ of the respondents.

Conclusion: This study shows that the knowledge of the dental therapy student in Enugu is good and can be said to be adequate. She is also putting that knowledge to practice in her personal life and dental practice.
\end{abstract}

Keywords: Toothbrush; Knowledge; Practice; Enugu

\section{Introduction}

Toothbrush is the single most common oral care item found in most homes that can be used individually to maintain an accept- able oral hygiene status and preventable oral infections, dental caries and periodontal diseases to mention a few [1]. However, while not discouraging the use of toothbrush, there is the believe 
that toothbrush could be a pool where large amount of various oral microorganism populates freely and this can lead to serious oral infections [2]. These microorganism when present even in small quantity among healthy subjects, can contaminate a newly sterilized toothbrush immediately on first use and then increase proportionally on the same toothbrush with repeated use [3,4]. However, a good knowledge of the care of the toothbrush and the practice of changing the toothbrush every 3 - 4 months according to the recommendations of experts such as the American Dental Association [1] could lead to the prevention of these microorganism accumulating on the toothbrush.

The dental therapist in Nigeria is trained among other things, to give oral hygiene instructions, demonstrate the effective use of the toothbrush to the patient and carry out prophylactic cleaning of the teeth through scaling and polishing; these functions are similar to the training and functions of the dental hygienist in American [5,6]. Toothbrushes are divided into three types according to the texture of their bristles which are soft, medium and hard bristles. Effective use of the toothbrush according to the American dental association for at least twice daily can reduced plaque in the teeth to a clinically significant level [7]. Acceptable oral hygiene practices such as the regular and effective use of the toothbrush, proper care of the toothbrush, when taught to children at an early age, prevents dental caries and periodontal diseases [8]. Furthermore, it has been reported that sufficient knowledge and education on the benefits of the use of toothbrush would motivate the populace in carrying out regular toothbrushing [8]. On the other hand, when this knowledge is lacking as reported in India [8], due to inadequate public enlightenment on the health benefits of good oral hygiene practices, children who are the most vulnerable have resorted to the use of traditional oral health practices instead of the toothbrushing [8]. The dental therapist in Nigeria like her counterpart in the United States of America has a 4 years training and works under the supervision of the dental surgeon [9].

\section{Objectives of the Study}

Is the dental therapist training in Nigeria is adequate to equip her to carry out the functions of educating patients on acceptable oral hygiene practices such as the regular and effective use of the toothbrush?

Secondly, this research seeks to find out if the dental therapist is putting into practice her knowledge in her daily life since she must believe in it to be able to motivate her patients?
It is the believe of the authors that answers to these questions would be used to adjust the training of the dental therapist and motivate her on the important role she plays in oral health care management.

\section{Materials and Methods}

This a descriptive cross-sectional questionnaire-based survey among 370 students in third- and fourth-year Dental therapy students at the Federal College of Dental Technology, Trans-Ekulu, Enugu State, Nigeria. Ethical clearance was obtained from the federal capital territory Health, research and ethics committee. The questionnaire was made up of three sections with the first section, Section A consisting of the biodata such as age, sex and marital status of the student; section B consist of five Likert-scaled questions which was used to determine the knowledge of the respondents while the final part Section C consist of close-ended questions to determine if respondents were putting knowledge to practice.

Data collected were entered, cleaned, and analysed using SPSS statistical package, version 20. Summary statistics and frequency tables were done for all variables. Chi-square test was used to investigate associations between variables.

\section{Results}

Socio-demographic characteristics of respondents

\begin{tabular}{|l|c|c|}
\hline $\begin{array}{l}\text { Socio-demographic } \\
\text { Characteristics } \mathbf{( N ~ = ~ 2 8 0 )}\end{array}$ & Frequency & Percentage \\
\hline Gender & \multicolumn{2}{|l|}{} \\
\hline Male & 206 & 26.4 \\
\hline Female & & 73.6 \\
\hline Age & 172 & 61.4 \\
\hline$\leq 25$ years & 108 & 38.6 \\
\hline$>25$ years & 186 & 66.4 \\
\hline Ethnicity & 42 & 15.0 \\
\hline Ibo & 36 & 12.9 \\
\hline Yoruba & 16 & 5.7 \\
\hline Hausa & \multicolumn{2}{|l}{} \\
\hline Others & 132 & 94.3 \\
\hline Marital status & 8 & 5.7 \\
\hline Single &
\end{tabular}

Table 1: Socio-demographic characteristics of dental therapist. Mean age $24.93 \pm 2.597$ years. 
The socio-demographic characteristics of the respondents are presented in table 1 . Results showed that most of the participants were aged 25 years and below (61.4\%) with the mean age of 24.93 \pm 2.597 years. Majority of them were female $(73.6 \%)$ and single (94.3\%). Many were of Ibo ethnicity (66.4\%).

Knowledge of tooth brushing of dental therapist

\begin{tabular}{|l|c|c|}
\hline $\begin{array}{l}\text { Characteristics } \\
\text { (N= 280) }\end{array}$ & $\begin{array}{c}\text { Good } \\
\text { Knowledge }\end{array}$ & $\begin{array}{c}\text { Fair } \\
\text { Knowledge }\end{array}$ \\
\hline $\begin{array}{l}\text { Toothbrush to be } \\
\text { changed every three } \\
\text { months }\end{array}$ & $280(100)$ & 0 \\
\hline $\begin{array}{l}\text { Hard toothbrush could } \\
\text { injure the gums }\end{array}$ & $204(72.9)$ & $76(27.1)$ \\
\hline $\begin{array}{l}\text { Toothbrushing twice } \\
\text { daily }\end{array}$ & $280(100)$ & 0 \\
\hline $\begin{array}{l}\text { Best toothbrushing habit } \\
\text { is first before meals in } \\
\text { the morning and last } \\
\text { thing after dinner }\end{array}$ & $4(1.4)$ & $276(98.6)$ \\
\hline $\begin{array}{l}\text { Toothpaste } \\
\text { recommended for } \\
\text { children is not harmful } \\
\text { when swallowed }\end{array}$ & $280(100)$ & $0(3.6)$ \\
\hline $\begin{array}{l}\text { Toothbrushing in } \\
\text { children begin imme- } \\
\text { diately after first milk } \\
\text { teeth appear }\end{array}$ & $276(98.6)$ & $4(1.4)$ \\
\hline $\begin{array}{l}\text { Toothbrush should be } \\
\text { kept upright to dry-air }\end{array}$ & $280(100)$ & 0 \\
\hline $\begin{array}{l}\text { It is not recommended to } \\
\text { keep toothbrush in the } \\
\text { bathroom }\end{array}$ & $270(96.4)$ & 0 \\
\hline $\begin{array}{l}\text { Bathroom with } \\
\text { attached toilet is also not } \\
\text { recommended to keep } \\
\text { toothbrush }\end{array}$ & $280(100)$ & 0.4 \\
\hline Knowledge & & \\
\hline Poor & & \\
\hline Fair & & \\
\hline Good & & \\
\hline
\end{tabular}

Table 2: Knowledge of tooth brushing by dental therapist.

All the participants in the study correctly agreed that toothbrush should be changed every three months. Majority of them
(98.6\%) agreed that toothbrushing in children should begin after milk teeth appear, however only 2 (1.4\%) of them correctly agreed that the option of using the brushing first before breakfast and last thing after dinner was the best toothbrushing habit.

Most of the study participants (72.9) agreed that the toothbrush with hard bristle could injure the gums and all the participants agreed with the idea of placing the toothbrush upright to air-dry, that is not covered. Additionally, 270 (96.4\%) agreed that it is wrong to keep toothbrush in the bathroom, while $100 \%$ would not recommend keeping toothbrush in a bathroom with attached toilet.

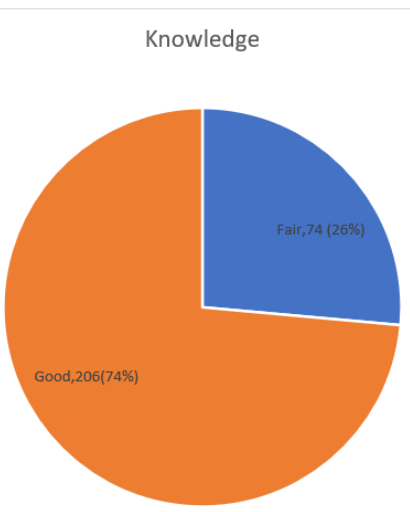

Figure 1: Summary the of knowledge of toothbrush.

Majority of the students of Dental therapy in Enugu, representing 74\% (206) have good knowledge of toothbrushing when compared with the $26 \%$ (74) that have fair knowledge. There was none with a poor knowledge signifying that their training was effective.

\section{Tooth brushing practice of dental therapy}

Students training as Dental therapist were demonstrating to the children they meet in their training, the effective use of toothbrush and motivating the children with dental education. However, only a very a few of the respondents (1.4\%) practice the decontamination of toothbrush with Chlorhexidine gluconate while, the entire number that participated in this study changed their toothbrush every 3 months and they also recommended same practice to their patients. 


\begin{tabular}{|l|c|c|}
\hline Characteristics (N= 280) & $\begin{array}{c}\text { Good Practice } \\
\text { N (\%) }\end{array}$ & $\begin{array}{c}\text { Fair Practice } \\
\text { N (\%) }\end{array}$ \\
\hline $\begin{array}{l}\text { Use toothbrush and } \\
\text { toothpaste for patients }\end{array}$ & $254(90.7)$ & $26(9.3)$ \\
\hline $\begin{array}{l}\text { Teach Horizontal brushing } \\
\text { techniques for children }\end{array}$ & $234(83.6)$ & $46(16.4)$ \\
\hline $\begin{array}{l}\text { Children toothpaste is } \\
\text { different from adult } \\
\text { toothpaste }\end{array}$ & $256(90)$ & $24(10)$ \\
\hline $\begin{array}{l}\text { Store toothbrush upright to } \\
\text { air-dry after use }\end{array}$ & $280(100)$ & 0 \\
\hline $\begin{array}{l}\text { Will not store toothbrush } \\
\text { enclosed in a can }\end{array}$ & $280(100)$ & 0 \\
\hline $\begin{array}{l}\text { Unacceptable practices for } \\
\text { care of toothbrush }\end{array}$ & $276(98.6)$ & $4(1.4)$ \\
\hline $\begin{array}{l}\text { Water to clean toothbrush } \\
\text { after use }\end{array}$ & $280(100)$ & $276(98.6)$ \\
\hline $\begin{array}{l}\text { Use of Chlorhexidine } \\
\text { gluconate or Sodium } \\
\text { Hypochlorite for } \\
\text { contamination control in } \\
\text { toothbrush }\end{array}$ & $\begin{array}{l}\text { Recommendation for } \\
\text { changing toothbrush }\end{array}$ & 0 \\
\hline $\begin{array}{l}\text { Effective use of toothbrush in } \\
\text { children }\end{array}$ & $280)$ \\
\hline
\end{tabular}

Table 3: Tooth brushing practice of dental therapy.

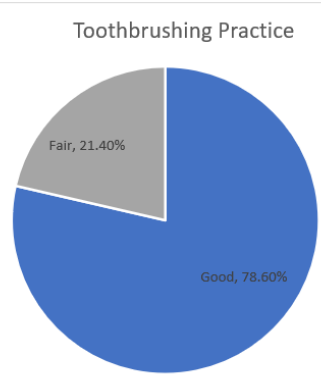

- Good " Fair "

Figure 2: Summary of toothbrush practice.
The toothbrushing practice of respondents was good as shown by the $78.60 \%$ that did it regularly as against the $21.40 \%$ that were fair. This signifies that the students are putting knowledge to practice in their daily life, and they are thus in a better position to educate and motivate their patients.

Association between respondents' sociodemographic characteristics and knowledge of toothbrushing

\begin{tabular}{|l|c|c|c|c|}
\hline $\begin{array}{l}\text { Socio-demographic } \\
\text { Characteristics }\end{array}$ & \multicolumn{2}{|c|}{$\begin{array}{c}\text { Toothbrushing } \\
\text { knowledge }\end{array}$} & $X^{2}$ & P value \\
\hline Gender & & & & \\
\hline Male & $52(70.3)$ & $22(29.7)$ & 0.282 & 0.595 \\
\hline Female & $154(74.8)$ & $52(25.2)$ & & \\
\hline Age & & & & \\
\hline$\leq 25$ years & $130(75.6)$ & $42(24.4)$ & 0.463 & 0.496 \\
\hline$>25$ years & $76(70.4)$ & $32(29.6)$ & & \\
\hline Ethnicity & & & & \\
\hline Igbo & $140(75.3)$ & $46(24.7)$ & 11.086 & $0.011^{*}$ \\
\hline Yoruba & $38(90.5)$ & $4(9.5)$ & & \\
\hline Hausa & $6(44.4)$ & $20(55.6)$ & & \\
\hline Others & $12(75)$ & $4(25)$ & & \\
\hline Marital status & & & & \\
\hline Single & $194(73.5)$ & $70(26.5)$ & 0.009 & 1.000 \\
\hline Married & $12(75)$ & $4(25)$ & & \\
\hline
\end{tabular}

Table 4: Association between respondents' sociodemographic characteristics and knowledge of toothbrushing.

*: Level of statistical significance.

Results showed that only ethnicity was statistically significantly associated with knowledge of toothbrushing $(\mathrm{P}<0.05)$.

Other socio-demographic characteristics including gender, marital status and age were not statistically significantly associated with knowledge of toothbrushing $(\mathrm{P}>0.05)$.

Association between respondents' sociodemographic characteristics and toothbrushing practice

Results showed that none of the sociodemographic characteristics were statistically significantly associated with toothbrushing practices $(\mathrm{P}>0.05)$. 


\begin{tabular}{|l|c|c|c|c|}
\hline $\begin{array}{l}\text { Socio-demographic } \\
\text { Characteristics }\end{array}$ & \multicolumn{2}{|c|}{$\begin{array}{c}\text { Toothbrushing } \\
\text { knowledge }\end{array}$} & $\mathbf{X}^{2}$ & P value \\
\hline Good & Fair & & \\
\hline Male & $56(75.7)$ & $18(24.3)$ & 0.250 & 0.644 \\
\hline Female & $164(79.6)$ & $42(20.4)$ & & \\
\hline Age & & & & \\
\hline$\leq 25$ years & $134(77.9)$ & $38(22.1)$ & 0.058 & 0.809 \\
\hline$>25$ years & $86(79.6)$ & $22(20 / 4)$ & & \\
\hline Ethnicity & & & & \\
\hline Ibo & $148(79.6)$ & $38(20.4)$ & 5.944 & 0.114 \\
\hline Yoruba & $26(61.9)$ & $16(38.1)$ & & \\
\hline Hausa & $30(83.3)$ & $6(16.7)$ & & \\
\hline Others & $16(100)$ & 0 & & \\
\hline Marital status & & & & \\
\hline Single & $208(78.8)$ & $56(21.2)$ & 0.064 & 0.680 \\
\hline Married & $12(75)$ & $4(25)$ & & \\
\hline Knowledge & & & & \\
\hline Good & $162(78.6)$ & $44(21.4)$ & 0.001 & 0.973 \\
\hline Fair & $58(78.4)$ & $16(21.6)$ & & \\
\hline
\end{tabular}

Table 5: Association between respondents' sociodemographic characteristics and toothbrushing practice.

\section{Discussion}

The strategic position the dental therapist in Nigeria occupies in the country's Health care system is such that their knowledge and practice can impart positively on their patients when the knowledge is adequate and the practice is of acceptable level. This descriptive study was done among 280 dental therapist students which consisted of $26.4 \%$ male and $73.6 \%$ female. The school is located in eastern Nigeria and this probably explains the reason why $66.4 \%$ of the respondents are of the Igbo ethnicity, the people who are mainly in eastern Nigeria. The Igbos as a people are known to practice business apprenticeship where a male in the family spend time under the mentorship of an older family member or a friend from the same community, learning a trade over a period, after which he celebrates "freedom" and starts his own trade [10]. This might explain why this study has more females than males who might have left home early in age to learn a trade or engage in some form of commercial business [10].
The knowledge of the use of toothbrush was found to be good among respondents, with females reporting a better knowledge at $74.8 \%$ compared to their male counterparts. In this study, changing of toothbrush every 3 months was accepted as the best practice by $98.6 \%$ of the participants and this is in consonance with Kumar., et al. who recommended in their study that the replacement of the tooth brush should be done periodically [11]. The importantance of this habit is to reduce the quantity of microorganism that contaminates the toothbrush resulting in a poor oral hygiene status [12-14]. In addition, $98.6 \%$ of the students in this study recommened that toothbrushing should start early in age and this too is in line with the study of Leal., et al. who agreed in their research which was done in Brazil stating that children were able to learn different toothbrushing techniques which resulted in adequate plaque control, although children above 5 years of age are believed to exhibited better toothbrush dexterity and were able to learn more toothbrushing techniques [15]. It was also noticed in this study that the association between respondents' sociodemographic characteristics and knowledge of toothbrushing was high among the Igbos and was statistically significant. However, this cannot be conclusive since the study was done among a predominately Igbo population in Eastern Nigeria, which is their hometown. This assertion is evident in the study of Akinyamoju., et al. on oral health knowledge and practice which was carried out in a predominately Yoruba population in Ibadan, Western Nigeria, the hometown of the Yoruba and as expected, the Yoruba ethnic group were in the majority in that study and reported to have better oral health Knowledge and practice than other ethnic groups [16].

While not favouring one toothbrushing techniques over the other, $83.6 \%$ of the respondents agreed that children can be taught a variety of toothbrushing methods early in age so that toothbrushing, as a habit, is ingrained in them early. Muller-Bolla and Courson believed while the horizontal method was the most favourable for children up to the ages of 6 to 7 years of age, there was no statistical difference in its effectiveness to reduce plaque when compared with other techniques [17]. Nevertheless, the emphasis is on teaching children below 5 years old, a simple and effective toothbrushing method which they can perform easily due to their age and this can be improved on as they grew older [15]. Proper practice of storing the toothbrush in an open area environment, standing upright to air-dry was done by $90 \%$ of respondents, although Naik., et al. disagrees that this practice alone is not sufficient to decontaminate the toothbrush [18]. Furthermore, respondents did not practice 
or recommend the storing the toothbrush in the toilet or a toilet with attached bathroom environment because of the high presence of pathogens that are deleterious to the oral health that would contaminate the toothbrush in these environment [18]. Practices such as not using the toothbrush at least twice daily $[19,20]$, not changing the toothbrushing every 3 months [11] and not using a toothbrush with a toothpaste [19] were unacceptable practices to all $(100 \%)$ the respondents. Using water to rinse the toothbrush was the frequent practice to clean the toothbrush for $98.6 \%$ of the respondents since the use of any chemical decontaminate like chlorhexidine gluconate or Sodium hypochlorite diluted in water [18] was only known to $4 \%$ of the respondents.

\section{Conclusion}

This study was conducted among the dental therapist students in Enugu, Nigeria and has shown that the dental therapist's training has equipped her with sufficient knowledge of the toothbrush and she is putting that knowledge to practice. Thus, she is in prepared to effect a positive change by impacting that knowledge to her patient which would go a long way to improving preventive dentistry and behavioral change in her patient. However, to keep up with current changes in Dentistry, continous dental education by attending conference and update lectures is highly recommended and of paramount importance. It would be interesting to find out if these knowledge and practise is the same in other dental schools in Nigeria.

\section{Acknowledgement}

I wish to acknowledge the support of all my industrial attachment students from the Federal College of Dental Technology, Trans-Ekulu, Enugu, that spent 2018 session in State House Clinic on attachment in the Dental and maxillofacial department for assisting in the distribution of the questionnaires. I also wish to take Miss Busayo Immaculate Oludare, the dental therapist on National Youth Service Corp (NYSC), who coordinated the industrial attachment students for this research.

\section{Bibliography}

1. Kumar G., et al. "Assessment of Knowledge, Attitude, and Practice of Dental and Medical Interns toward Toothbrush Maintenance and Replacement in Bhubaneswar City, Odisha, India". Journal of Pharmacy and Bioallied Sciences 10.2 (2018): 77-82.

2. Petersen PE. “The World Oral Health Report 2003: Continuous improvement of oral health in the $21^{\text {st }}$ century-the approach of the WHO Global Oral Health Programme". Geneva: World Health Organization (2003).

3. Kozai K., et al. "Residual contamination of toothbrushes by microorganisms". Journal of Dentistry for Children - AAPD 56 (1989): 201-204.

4. Verran J and Leahy-Gilmartin AA. "Investigations into the microbial contamination of toothbrushes". Microbios 85 (1996): 231-238.

5. Ikimi NU., et al. "Hand Hygiene: Knowledge and Practice of Dental Therapists in Abuja, Nigeria”. Acta Scientific Dental Sciences 2.5 (2018): 02-07.

6. Calache H and Hopcraft MS. "The Role of the Oral Health Therapist in the Provision of Oral Health Care to Patients Across All Ages". Medicine (2012).

7. Creeth JE., et al. "The effect of brushing time and dentifrice on dental plaque removal in vivo". The Journal of Dental Hygiene 83.3 (2009): 111-116.

8. Gopikrishna V., et al. "Knowledge, attitude, and practices of oral hygiene among college students in Bengaluru city". Journal of Indian Association of Public Health Dentistry 14 (2016): 75-79.

9. Mathu-Muju KR. "Chronicling the dental therapist movement in the United States".jphd_270 (2011): 288.

10. Agozino B and Ayanike I. "IMU AHIA: Traditional Igbo Business School and Global Commerce Culture". Dialectical Anthropology 31 (2007): 233-252.

11. Kumar G., et al. "Assessment of Knowledge, Attitude and Practice of Dental and Medical Interns toward Toothbrush Maintenance and Replacement in Bhubaneswar City, Odisha, India". Journal of Pharmacy and Bioallied Sciences 10.2 (2018): 77-82.

12. Caudry SD., et al. "Contaminated toothbrushes, and their disinfection". Journal of the Canadian Dental Association 61 (1995): 511-516.

13. Daly CG., et al. "Effect of toothbrush wear on plaque control". Journal of Clinical Periodontology 23 (1996): 45-49.

14. Attin T and Hornecker E. "Tooth brushing and oral health: how frequently and when should tooth brushing be performed?" Oral Health and Preventive Dentistry 3 (2005): 135-140. 
15. Leal SC., et al. "Effectiveness of teaching methods for toothbrushing in preschool children". Open Access Brazilian Dental Journal 13.2 (2002): 133-136.

16. Akinyamoju CA., et al. "Oral Health Knowledge and Practice Among Traders in Ibadan". Annals of Ibadan Postgraduate Medicine 16.2 (2018): 150-156.

17. Muller-Bolla M and Courson F. "Toothbrushing methods to use in children: a systematic review". Oral Health and Preventive Dentistry 11.4 (2013): 341-347.

18. Naik R., et al. "Contaminated toothbrushes-potential threat to oral and general health". Journal of Family Medicine and Primary Care 4.3 (2015): 444-448.

19. Gopikrishna V., et al. "Knowledge, attitude, and practices of oral hygiene among college students in Bengaluru city". Journal of Indian Association of Public Health Dentistry 14 (2016): 75-79.

20. Cheah WL., et al. "Oral health knowledge, attitude and practice among secondary school students in Kuching, Sarawak". Archives of Orofacial Sciences 5 (2010): 9-16.

\section{Volume 5 Issue 10 October 2021}

(C) All rights are reserved by Nathan Ukuoghene Ikimi., et al. 